\title{
Consider Sequestering Geniuses
}

\author{
Paul TE Cusack* \\ Independent Researcher, Canada
}

Received: 阱 September 29, 2018; Published: 制 October 09, 2018

*Corresponding author: Paul TE Cusack, Independent Researcher, Canada

\begin{abstract}
Here we provide a brief examination of how to improve the productivity of geniuses by sequestering them into a venue where they are free from the struggles of ordinary schools. The conclusion reached is that the present system is probably the best we can do for them.
\end{abstract}

Keywords: Genesis; Psychology

\section{Opinion}

I have often turned over the question in my mind about whether a genius should be sequestered at an early age to produce and protect the hegemony that he or she bares to propel humanity forward faster, if ever at all. The answer to that question is inconclusive but tends toward the system that is presented today. The answer to that question is not so simple as might be anticipated. The system is place today may not be able to be improved upon. In the following paragraphs, I shall consider the present situation to see where various avenues lead about sequestering geniuses. So, should a young genius be sequestered from the regular school system to increase his or her long-term productivity that will benefit humanity? We begin by defining a few notions: First, how young are we talking about? Kindergarten? Grand school? High School? And how do we define a genius? Ninety-eight percentile on the IQ test? And what is the purpose of sequestering a genius so defined? To provide a sheltered environment so that he can be more productive and protected? These are just some questions that arise from the suggestion of sequestering a genius. We will assume a genius would be sequestered at a very early age, say 6-7 years old. We will assume that the genius is someone would be thought of as truly gifted or outstanding in his or her work. A sheltered environment means an institution whereby the genius is protected from the normal wear and tear of afflictions suffered from jealously by both adults and other class mates. Second, would we truly see an increase in productivity if a genius were sequestered? The argument is often made that the socialization in school is important. Some today think it is paramount. They argue that EQ or the emotional quotient, is a better measure of potential success. It is my opinion that EQ is simply the ability to lie well whereas IQ measures the ability to see truth. Yes, people with higher EQ's do better themselves in life because being a better liar has its advantages. That's why people lie. How do we test for creativity? Creativity is the most important aspect of genius. Mere fact grinding may produce valedictorians; but not geniuses. A test would necessarily have to be devised to test for creativity along with IQ. Some argue that all children of any ability should all be put together in the same class because "they are not separated when they get out" (of school). If we use the sports analogy, where winning is everything, imagine putting NHL Hockey stars on a team with below average players. It doesn't serve the society well. How much more so with academics that determine if we find that next cure for cancer or solve an unsolved math problem. First, some argue that the geniuses are sequestered now in the sense that we have Private Schools, College Prep High Schools, and Ivy League Universities. And scholarships provide some funding at least for a few scholars. Fellowships are available for those who meet the stringent requirements. But all geniuses don't get into Harvard nor do they obtain scholarships.

Second, we seem to treat superb athletes better than we treat geniuses. Athletes get recruited in High School and are nursed through the universities to go on to professional sports. American universities spend countless millions on their sports programs all in the name of producing the best athletes. Shouldn't they do at least the same for a genius who may go on to alter the world? Do they do enough now? If we assume that a genius can be determined at an early age via the IQ and Creativity test, and that it is advantageous to separate him or her from the average students, would we see an increase in productivity for humanity? Sometimes it takes years before a genius blossom. They mature 
at different rates. And would the system being tampered with by teachers and other administrators as they presently do in the government run system? Children who excel may be looked over in favor of a teachers own children or their friends as they do now. It's not a level playing field. We touched on socialization. One professor lamented that the "socialization" in school is "overrated." However, there is a need among people - especially young people - to socialize most importantly in the mid-teens to their thirties. Sequestering a genius during this period would be devastating for him or her. While it is true that the genius could socialize with other geniuses, the question remains whether "other geniuses" are any bit superior that the regular students. My experience is that they are not. Goodness or badness knows such bounds. Sequestering the genius would not necessarily produce more productive nor protect him anymore that the present government backed schools. Some of the same issues arise when considering homeschooling. Young minds need exposure to wholesome and qualified teachers. The student suffers from not being engaged with adult teachers. I have not found any superiority in people of varying social class. Bad apples exist in the richest and poorest neighborhoods. Criminal behavior knows no social bounds. Sequestering the genius with other geniuses would not provide a more sheltered environment for them to flourish. The idea of putting all students together no matter their ability goes to the heart of one's philosophy viz. What are we hear for? If we are here for a short time to see if we make the pass to get to Heaven, then mixing of abilities could make sense. If on the other hand, your philosophy is such that we are here to conquer

DOI: $10.32474 /$ SJPBS.2018.01.000118 nature are read the mind of God, then sequestering the genius is probably reasonable. Advancing humanity in this way takes place in spirts by the works of geniuses usually working alone. Right now, the government funded school system is built for average people-in fact the whole world is built for average people. We see incomes drop like a stone for people with IQ over the 85 percentiles. Surely as a society we need the works of geniuses desperately to solve growing problems. The way we treat the genius will determine the fate of humanity. We need to make use of every sharp tool we have and not squander genius in the name of inclusion. Teaching the genius how to defend himself /herself physically might be the most effective strategy there is to fend off bullies. In my experience, it's a sad fact that many humans are not truly human. By throwing the genius into an environment where he or she is forced to fend for himself/ herself is regrettable and unproductive. The world needs productive geniuses more than anything else to solve the problems facing humanity.

\section{Conclusion}

I don't think a publicly funded school system can adequately determine who are the geniuses at an early age nor treat them fairly. The present system may be the best we can do, given that there are opportunities for enriched studies and prestigious universities which have demanding admissions requirements. Therefore, the answer to the question of how geniuses should be handled at an early age to produce the most productive citizens of the world is inconclusive.

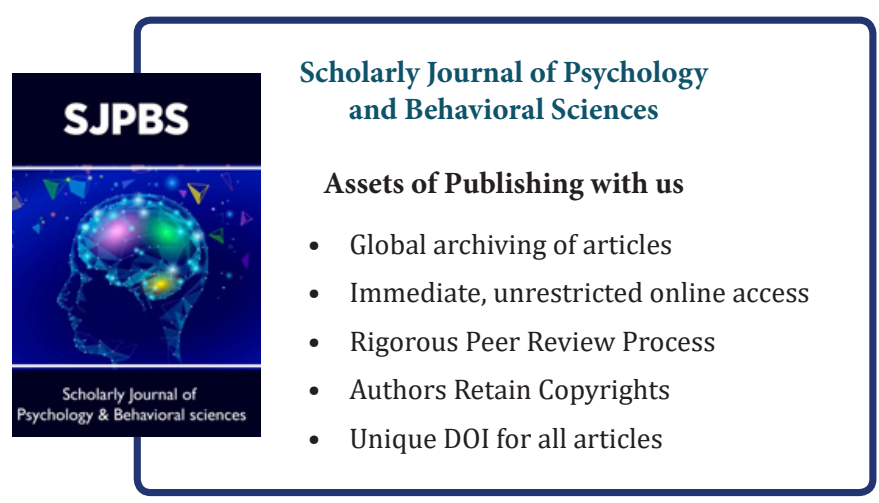

